\title{
Bioética en el impacto del proyecto del Genoma Humano
}

REV EXP MED $2021 ; 7(2)$.

\section{Bioethics on the impact of the Human Genome project}

\section{Sr. Editor:}

Durante el mes de febrero, tuve la oportunidad de investigar sobre el desarrollo del estudio del Genoma Humano y las repercusiones en nuestras vidas, un tema de mucha actualidad, discrepancias, polémicas y retos.

Ante esto, se realizó una búsqueda bibliográfica, utilizando descriptores de salud como: "Bioethics, Bioética, Bioética" y "Human genome, Genoma Humano, Genoma Humano" en los idiomas: inglés, castellano y portugués respectivamente, junto con los conectores AND y OR, encontrando artículos relevantes en los buscadores como SCOPUS, PUBMED y SCIELO.

Según la información encontrada, la Organización Mundial de la Salud (2002) estipula que el uso de la genética en el campo de la salud es puramente con fines terapéuticos. Gracias al desarrollo, en la segunda mitad del siglo XX hasta nuestros días, el término tecnociencia (1) generó importancia en el estudio del Genoma Humano. En 1953 Francis Crick y James Watson, desentrañaron la estructura en doble hélice del ADN y el 14 de abril del 2003 el Human Genome Project lograba completar el mapa del genoma humano definiéndolo como: "El conjunto de genes que constituyen cada ser vivo. En el ser humano, son aproximadamente tres mil millones de pares de bases de ADN, distribuidos en 23 pares de cromosomas, los cuales contienen entre 70 y 100 mil genes" (2).

Sumado a esto, el descubrimiento del CRISPR / Cas9 en 2012 por Charpentier y Doudna, trajeron como consecuencia, "Los objetivos y métodos de la genómica en salud" (1), los cuales se enfocarían en conocer su estructura, identificar mutaciones, predecir enfermedades, nuevas terapéuticas como la terapia genética, su edición e investigación de células madre para clonación terapéutica, además de prevención de enfermedades de origen genómico, diversidad genética, identificación humana, uso forense, etc.

Entonces, ¿Qué impacto genera la Bioética en el estudio del Genoma Humano? ¿Contribuye al desarrollo o al atraso? o ¿Sólo busca polémica? Los problemas empezarían en diagnosticar alguna patología causada por genes en el embarazo y se abriría debate si "¿Se podría modificar o no modificar el genoma de nuestra descendencia?" (3). Predecir la aparición de una enfermedad total o parcialmente genética donde la solución sería la "adición o supresión de genes" (4) y la confidencialidad de los resultados de estudios genéticos donde se prioriza la discriminación de ciertas bases genéticas y por ende la "pérdida de la biodiversidad, sobre la inequidad, y la posibilidad de una eugenesia, definir los límites entre lo artificial y lo natural y los desafíos en el cuidado de la salud" (5).

Para esto, el "Comité Internacional de Bioética de la UNESCO (CIB)" (6) publicó la Declaración Universal sobre el Genoma y los Derechos Humanos, el cual se encargaría de defender la dignidad humana, las personas interesadas, investigaciones, condiciones, cooperación, fomento y aplicación. Asimismo, el "Comité de asuntos legales y sociales HUGO"(6), recomendaría al genoma humano como patrimonio de la humanidad, aceptarse en normas internacionales, respetar la cultura, la dignidad y libertad humana. Por otro lado, se menciona la postura de la Iglesia católica que "Para encuadrar adecuadamente el tema de la edición genética, es necesario reflexionar brevemente sobre el significado de la técnica moderna y sobre esta particular técnica, la genética" (7).

\footnotetext{
${ }^{1}$ Universidad Señor de Sipán, Chiclayo, Perú.

a Estudiante de Medicina Humana.

${ }^{\mathrm{b}}$ Magíster en ciencias
} 
Por ende, la Bioética, brinda las herramientas para debatir sobre estos dilemas, recordando que "No debemos olvidar que las técnicas son éticamente neutras, depende del uso que se haga de ellas." (8). Además, debe plantearse como nuestra guía, soporte y rumbo, y la libertad que ésta debe de tener en el impacto del Genoma Humano para que no se abuse en la aplicación del mismo, el que, para algunos buscan una mejora eugenésica, ya sea en raza, apariencia, rasgos y de otra índole que al final solo estaría alimentando el ego y asuntos subjetivos no superados.

Invitaría a contemplar una de las maravillas que posee la persona humana, el Genoma Humano.

Conflictos de interés: Los autores declaran que no tienen conflicto de intereses.

Fuentes de financiamiento: Autofinanciado

\section{REFERENCIAS BIBLIOGRÁFICAS}

1. Penchaszadeh V. Bioética y Tecnociencia. Revista Escritos. 2016;24(51): 447-466. DOI: http://dx.doi.org/10.18566/escr.v24n53.a09

2. Naves J, Lazzarotto R. Derechos fundamentales, democracia y el Proyecto Genoma Humano; bioética y biopolítica. Revista Bioét. 2018; 26(4): 506-13. doi: 10.1590/1983-80422018264268

3. Beriain M. ¿Modificar o no modificar el genoma de nuestra descendencia? Algunos comentarios a raíz de la Declaración del Comité de Bioética de España sobre la edición genómica en humanos. Rev Bio y Der [Internet]. 2019 [citado el 12 de enero];(47): 55-75. Disponible en: http://scielo.isciii. es/scielo.php?script=sci_arttext\&pid=S1886-58872019000300006

4. Bergel D. El impacto ético de las nuevas tecnologías de edición genética. Rev Bioét. 2017; 25(3): 454-461. DOI: http://dx.doi.org/10.1590/198380422017253202

5. Rodriguez E. Desafíos éticos en investigación genómica y biotecnología. Veinte años de acta bioethica. Acta Bioethica [Internet]. 2020 [Citado el 12 de enero del 2021]; 26(2): 137-145. Disponible en: https://scielo.conicyt.cl/ pdf/abioeth/v26n2/1726-569X-abioeth-46-137.pdf

6. Lisker R. Aspectos Éticos del Proyecto Internacional: El Genoma Humano. Revista CONAMED [Internet]. 2021 [citado el 12 de enero 2021]; 5(10): 1-3. Disponible en: https://www.medigraphic.com/pdfs/conamed/con2001/con014c.pdf

7. Borgoño C. Reflexiones ético-teológicas ante la edición genética. Rev. Cuadernos de Bioética. 2019; 30(100): 289-302. doi: 10.30444/CB.40

8. Lacadena JR. Edición genómica: ciencia y ética. Rev Iberoamericana de Bioética. 2017;(3): 01-14. doi: https://doi.org/10.14422/rib.i03.y2017.004 